\title{
The Challenges of Online Learning During the Covid-19 Pandemic
}

\author{
Yustinus Budi Hermanto $^{1 *}$, Veronika Agustini Srimulyani ${ }^{2}$ \\ ${ }^{I}$ Departement of Management, Darma Cendika Catholic University, Surabaya, Indonesia \\ ${ }^{2}$ Departement of Management, Widya Mandala Surabaya Catholic University, Indonesia \\ *Corresponding author: Yustinus.Budi@ukdc.ac.id
}

\begin{abstract}
The Covid-19 pandemic requires almost all human activity to shift to digital media, including education services. Now, education services must adapt to online learning methods. This change is a challenge for Indonesian education, which must also prepare students to adapt to face the challenges of the era of Society 5.0. This study aims to obtain information about online learning from home during the Covid-19 pandemic at the junior, senior, vocational, and university levels in Indonesia. Researchers also analyzed the differences in the mastery of learning technology in students and educators. This study used a questionnaire distributed via Google forms to students and educators using Facebook, e-mail, and WhatsApp Group (WAG). The total sample in this study was 108 educators and 386 students. From the independent sample t-test test, the following results were obtained: the mastery ability of MS office software and online learning technology in students was higher than students with significant differences; there was no significant difference between teacher and lecturer perceptions regarding the role of learning technology in the classroom and on the educational process of students. The success of online learning was highly dependent on several integrated components, such as students, educators, learning resources, and the technology used. The researcher also found several disadvantages of online learning, such as student discipline, lack of internet access, and lack of social interaction, common challenges for educational organizations and stakeholders.
\end{abstract}

Keywords: Technology; Covid-19; Online Learning

$\begin{array}{lll}\text { History: } & \text { Publisher: Undiksha Press } \\ \text { Received } & : 31 \text { October } 2020 & \text { Licensed: This work is licensed under } \\ \text { Revised } & : 1 \text { November } 2020 & \text { a Creative Commons Attribution 3.0 License } \\ \text { Accepted }: 26 \text { January } 2021 & \\ \text { Published }: 25 \text { April } 2021 & \end{array}$

\section{Introduction}

Corona Virus Disease, better known as Covid-19, is a new type of coronavirus that attacks the human respiratory system (Pratiwi, 2020; Wijayanengtias \& Claretta, 2020). The disease was first identified in December 2019 in Wuhan, the capital of China's Hubei Province, and has since spread globally throughout the world without exception. This condition affects every sector of human life very quickly. The Covid-19 pandemic has caused unprecedented damage to the education system throughout the world. In addition to measurable economic impacts in the short and long term, there is an intangible collapse in educational institutions (Basilaia \& Kvavadze, 2020). In particular, educators, the most critical intellectual resources of any educational organization, must face various types of difficulties, including financial, physical, and mental, because of COVID-19.

Reducing the number of people with Covid-19, the Minister of Education and Culture issued a circular on March 24, 2020; regulates the implementation of education during the emergency spread of Covid-19, as is also done by many countries. Provincial and local 
governments issued policies to temporarily eliminate face-to-face learning, which was replaced by 'study from home' through online or online learning. This policy applies at the elementary, secondary, and university levels. This step is considered appropriate to prevent the spread of Covid-19 in the school or campus environment, although a limited initial survey conducted by some researchers showed that implementation in the field is still diverse. Online learning can be an effective solution for activating classrooms even though schools or universities have been closed, given the enormous risks during this pandemic (Herliandry et al., 2020). Besides, the ability to master technology by educators would be increasingly encouraged to become better with online learning (Miaty, 2020).

Learning is a process built to develop students' creative thinking (Widodo \& Kadarwati, 2013). Meanwhile, the term 'daring' is an abbreviation of 'Dalam jaringan,' which is the Indonesian substitute of the word 'online that is often related to internet technology. The learning process, whether using learning applications or social networking, is called online learning. According to Basilaia \& Kvavadze (2020), online learning is the experience of knowledge transfer using video, audio, images, text communication, and software supported by internet networks (Zhu \& Liu, 2020). The essential factor in online learning is the readiness of educators and students to interact online.

In education, the era of society 5.0 allows students to directly interact with robots specifically designed to replace educators or be remotely controlled by educators in the learning process (Elsy, 2020; Nastiti \& Abdu, 2020). Current technological developments enable online learning to be implemented well. The technology adopted in education today has led to a variety of new learning models. Some of these models are learning with the help of electronic devices (e-learning), such as Compact Discs, which contain material to be studied and distributed by post; distance learning (distance learning); and also online learning, where learning material/media is placed on a server that can be accessed via the internet. According to Gikas \& Grant (2013), the implementation of online learning requires mobile devices such as smartphones, tablets, and laptops that can be used to access information anywhere and anytime. Abidah et al. (2020) discussed various infrastructures that supported online learning for free, simple, and could be accessed using smartphones, namely various discussion rooms such as Google Classroom, WhatsApp, Kelas Cerdas, Zenius, Quipper, and Microsoft. Online learning could even be done through social media, such as Facebook and Instagram (Kumar \& Nanda, 2018).

The research conducted by Dewi (2020) showed that the implementation of online learning in elementary schools during the Covid-19 pandemic could be carried out quite well because of the collaboration between teachers, students, and parents in learning at home. Furthermore, the results of (Purwanto et al., 2020) studies that used 15 respondents consisting of teachers and parents in two elementary schools in Tangerang, Indonesia, showed several challenges and obstacles experienced by students, teachers, and parents in online learning. These challenges included limited communication related to socialization among students, challenges for students with special educational needs, and more extended screen time. On the other hand, parents thought that problems that arise were more related to the lack of discipline of learning at home, much time spent by parents to help children's learning at home (especially for children under Grade 4 in Primary Schools), lack of technical skills and higher internet bills. The results of Putria et al. (2020) found that there were several supporting factors for educators in the online learning process, namely the availability of smartphones, quotas, and a stable internet network because not all students have smartphones. The results of Zhang et al., (2020) research on online learning in several schools and universities in China during the Covid-19 pandemic showed ambiguity and disagreement about what to teach, how to teach, the workload of teachers and students, the environment teaching, and its implications for equitable education. Good relational 
coordination between teachers in e-learning is needed, such as providing routine and timely communication mechanisms and problem-solving to supported shared knowledge in the context of shared goals. In addition, mutual respect could lead to higher job satisfaction of teachers (Margalina et al., 2014).

The success of online learning systems is highly dependent on several integrated components between students, lecturers, learning resources, and existing technology (Mustofa et al., 2019). The results of Firman \& Rahayu (2020) showed that: (1) students already had the essential facilities needed to take part in online learning; (2) online learning was flexible in its implementation and able to encourage the emergence of learning independence and motivation to be more active in learning; (3) distance learning encouraged the emergence of social distancing behavior and minimized the emergence of crowds to reduce the potential for the spread of Covid-19 in the campus environment. Zhafira et al. (2020) proved that the most popular online learning media during Covid-19 social distancing were WhatsApp and Google Classroom. As many as 53\% of respondents were familiar with various online learning media before online lectures began. Furthermore, the most popular communication pattern was the semi-two-way pattern, so that further research was needed on online learning research with problem-based, collaborative, and other models.

The purpose of this study was to develop previous research on learning practices during Covid-19, to get information related to the implementation of online learning during SFH in several junior high schools (junior high schools), high school/vocational schools (SMA/K), and several universities (PT) in Indonesia, learning technology used by students, students, teachers and lecturers, mastery skills of MS office software and learning technology from students and students, teachers and lecturers. Another purpose of this study was to analyze the differences in the mastery of MS Office software and learning technology in students and students and differences in the perception of teachers and lecturers about the role of learning technology devices in the classroom on student learning.

\section{Materials and Methods}

This research was an exploratory case study to obtain information about the consequences of the Covid-19 pandemic on online learning and teaching in junior high schools, high schools, vocational schools, and universities. The population in this study were junior high school students and high school students, vocational high school students, university students, teachers, and lecturers in Indonesia. Considering that the population was substantial, to get a research sample, the distribution of questionnaires was carried out by random sampling using the google form application. This questionnaire was distributed to teachers, lecturers, students, and university students through Facebook, messenger, e-mail, and WhatsApp Group (WAG).

The distribution of questionnaires conducted by the random sampling method via the Google Form application to lecturers, teachers, university students, and students through Facebook, messenger, e-mail, and WhatsApp Group, 52 lecturers and 220 students from several universities were obtained. In addition, researchers also obtained 56 teachers and 166 junior highs, high school, and vocational students from various schools in Indonesia. Thus, the total sample in this study was 108 educators and 386 students.

The analysis technique used was descriptive and comparative analysis to analyze differences in Microsoft Office mastery and online learning technology between students and students and differences in teacher and lecturer perceptions regarding the role of learning technology in the educational process. Meanwhile, to analyze the differences in the mastery of learning technology between groups of students, an independent samples test was conducted using the IBM SPSS Statistics 22 program. 
Table 1. Respondent Group Details

$\left.\begin{array}{ccc}\hline \text { Group } & \text { Area of School or Universities } & \text { Total Respondents } \\ \hline \text { Teachers } & \text { East Java: } 22 \text { Schools } & 56 \\ \text { Central Java: } 3 \text { Schools } & \\ \text { Jakarta: } 1 \text { School } \\ \text { West Java: } 1 \text { School } \\ \text { Kalimantan: } 4 \text { Schools } \\ \text { East Java: } 9 \text { universities } \\ \text { Central Java: } 1 \text { university } \\ \text { Yogyakarta: } 2 \text { universities }\end{array}\right]$

\section{Results and Discussion}

Table 2 presented various learning tools used by students during the home form study. Researchers found various devices used, 156 students using smartphones and a combination of 108 students using a PC or laptop. The most used infrastructure of 156 students in online learning was the internet network, while the other infrastructure was textbooks and television. This finding was following Abidah et al. (2020), who found that online learning can use a simple and free application so that students can follow the learning process via smartphones. From the contents of the questionnaire about the impression of online learning, information was obtained that despite the many conveniences provided online learning through the internet, and students preferred face-to-face learning.

Table 2. Students Online Learning Tools During the Covid-19 Pandemic

\begin{tabular}{cc}
\hline Tools & Percentage (\%) \\
\hline Smartphone & 38.14 \\
Internet networking & 32.77 \\
Computer (PC or Laptop) & 26.40 \\
Smart Board & 1.22 \\
Etc (Book, TV, Module) & 1.47 \\
\hline Total & 100 \\
\hline
\end{tabular}

Table 3. University Students Online Learning Tools During the Covid-19 Pandemic

\begin{tabular}{cc}
\hline Tools & Percentage (\%) \\
\hline Smartphone & 43.60 \\
Computer (PC or Laptop) & 42.30 \\
Internet networking & 9.50 \\
Smartphone and Laptop & 4.60 \\
\hline Total & 100 \\
\hline
\end{tabular}


Table 3 showed that during SFH, the most widely used learning tools most university students were smartphones and computers (PCs or laptops) with internet supported. This finding was in line with Firman \& Rahayu's (2020) findings, which revealed that university students already had the essential facilities needed to participate in online learning. Thus, online-based learning in the industrial era 4.0 towards society 5.0 was not difficult because almost all students and educators already had smartphones or other devices to access this online-based learning. Meanwhile, students' online media most preferred in order were Google Classroom, WhatsApp Group, YouTube, Instagram, and Zoom (Mustakim, 2020; Zhafira et al., 2020).

Table 4. Teacher's Perception Related to Learning Technology in the Classroom

\begin{tabular}{lcc}
\hline \multicolumn{1}{c}{ Statement items/questions } & Average & Annotation \\
\hline $\begin{array}{l}\text { How good were you at using the internet in the classroom? } \\
\text { What was your impression about the technological tools used in } \\
\text { the education process? Does the tool contribute to the interaction } \\
\text { and concentration of students in the lesson? }\end{array}$ & 3.25 & High \\
$\begin{array}{l}\text { What was your impression about the tools of modern technology } \\
\text { used in the education process? Does the tool contribute to }\end{array}$ & 3.37 & High \\
students' high grades and student achievement? \\
$\begin{array}{l}\text { Technical people at your school actively contribute to enriching } \\
\text { technical tools in the classroom. }\end{array}$ \\
$\begin{array}{l}\text { The addition of new technological tools in the classroom will } \\
\text { have a significant impact on students' motivation and presence in } \\
\text { class. }\end{array}$ & 3.82 & High \\
\hline Average & High & \\
\hline
\end{tabular}

In Table 4, it can be seen that the internet usage of the teachers when in the classroom was at a High level. The teachers also had a positive impression of the technological tools used in education because they contribute highly to the interaction and concentration of students in lessons and students' grades and achievements. Furthermore, the technical staff supported in schools was also high because they actively contribute to enriching technical learning tools in the classroom. Thus, the addition of new technological tools in the classroom impacts increasing student motivation and attendance in class.

Table 5. Teacher Learning Tools in the Classroom

\begin{tabular}{cc}
\hline Tools & Percentage (\%) \\
\hline Computer (PC or Laptop) & 27.53 \\
Internet networking & 21.91 \\
Projector & 20.78 \\
Smartphone & 17.98 \\
Book, TV, Module & 8.99 \\
Smart Board & 2.81 \\
\hline Total & 100 \\
\hline
\end{tabular}

In Table 5, it could be seen that most of the learning devices used by teachers in the classroom were Internet-connected PCs or laptops, projectors (LCD), and smartphones. 
Table 6. University Students Online Learning Tools During the Covid-19 Pandemic

\begin{tabular}{cc}
\hline Tools & Percentage (\%) \\
\hline Smartphone & 34.81 \\
Internet networking & 34.81 \\
Computer (PC or Laptop) & 26.68 \\
LCD, Smart Board, WA, TV & 3.70 \\
\hline Total & 100 \\
\hline
\end{tabular}

In Table 6, it was evident that most of the learning tools used by teachers during LFH were smartphones and PCs or laptops connected to the internet. Online learning could occur because there were several supporting factors, including smartphones, quotas, and a stable and good internet network (Putria et al., 2020). In addition, there was a positive impression of the technological tools used in education because they contributed highly to the process of interaction and concentration of students in lectures and students' grades and achievements. Basri et al. (2018) showed that the adoption of ICT (information and communication technology) and student academic performance was positively and significantly related. Technical support on campus was felt high because they actively contributed to enriching the learning tools in the classroom. Thus, the addition of new technology tools in the classroom could impact increasing student motivation and attendance in class. Sianturi (2018) showed that internet usage on university students could significantly influence university students' motivation in using e-learning. Puspitasari et al. (2018) found that the use of instructional media significantly influenced students' motivation. Meanwhile, if online learning with the Edmodo application continued to be done, student achievement would increase, and the teacher would also save time and energy in the learning process (Sobron et al., 2019).

Table 7. Lecturer Learning Tools in the Classroom

\begin{tabular}{cc}
\hline Tools & Percentage (\%) \\
\hline Computer (PC or Laptop) & 32.03 \\
Internet networking & 24.18 \\
Projector (LCD) & 24.18 \\
Smartphone & 15.03 \\
Smartboard, whiteboard, speaker & 4.58 \\
\hline Total & 100 \\
\hline
\end{tabular}

Table 7 showed that most of the learning devices used by lecturers in the classroom were PCs or laptops connected to the internet, projectors (LCD), and smartphones.

Table 8. Lecturer Learning Tools During LFH

\begin{tabular}{cc}
\hline Tools & Percentage (\%) \\
\hline Internet networking & 42.30 \\
Computer (PC or Laptop) & 34.60 \\
Smartphone & 13.50 \\
Computer, smartphone, laptop, internet & 9.60 \\
\hline Total & 100 \\
\hline
\end{tabular}

In Table 8, it was evident that most of the learning tools used by lecturers during LFH were PCs or laptops and smartphones connected to the internet. The development of cheap and accessible information and communication technology in the Industrial 4.0 era towards 
Society 5.0. It had a significant influence on the teaching and learning process because it removes the limitations of space and time, which had so far restricted the world of education. Tables 11 and 12 showed that educators who use technology tools were supported by easy access to technology to improve the quality of learning.

\section{Advantages and Disadvantages of Online Learning during the Covid-19 Pandemic}

This finding was consistent with the results of previous studies that online learning had flexibility in its implementation and was able to encourage social distancing behavior, could reduce the potential for the spread of Covid-19 in the campus environment, and eliminate awkward feelings so students could express ideas, opinions and ask questions freely. Online learning also could provide students with more meaningful learning experiences (Sobron et al., 2019) and provided new experiences more challenging than conventional learning models (Kuntarto, 2017). The results of online learning English studies with complementary media web blogs proved that online learning could improve students' reading skills (Khusniyah \& Hakim, 2019).

The results support this result in supporting Briliannur et al. (2020), which shows that there is less effective online learning due to the lack of facilities and infrastructure and unpreparedness of technology education. This study supported Bøe (2018) findings, which proved that there was no significant relationship between teacher satisfaction to continue using e-learning technology. This is in line with china's national online learning experiments during the Covid-19 pandemic also showed many difficulties in their implementation, such as disadvantages in online teaching infrastructure, lack of teacher experience (including unequal learning outcomes caused by diverse teacher experiences), information gaps, environmental difficulties complex at home, lack of discipline, less effective online education processes, and long-term online teaching could have a negative impact on students' mental and physical health (Zhang et al., 2020). The Covid-19 pandemic situation is a situation where there was a sudden change from a study from school to study from home. It is an emergency, so education practitioners could not prepare learning systems and online learning materials maturely and systemically.

In table 14, we saw some of the disadvantages of online learning. According to the participants, they were less motivated, and there was also a significant increase in online assignments. Therefore, most of the student respondents expected more conventional learning models. On the other hand, educators felt fatigued and burnout. To overcome these challenges, educators needed creativity. They should place students as 'listeners' or 'viewers' and encourage their active participation to interact, dialogue, collaborate, share, and build knowledge together. If educators could make the learning process more fun, students would be more interested in participating in the learning process (Mustakim, 2020). Hikmatiar et al. (2020) proved that using Google Classroom as a learning medium positively impacted learning outcomes, interests, and motivation of students in learning and fostering creative attitudes towards students or students. However, it was not sufficient for specific subjects and subjects related to calculation and practice if only done through online learning. Mustakim (2020) argues that to increase the effectiveness of online learning, especially in the matter of calculation, it was better for the questions given to be more varied and different for each student. In addition, assignments must be included with an explanation of how to work.

\section{Independent Samples Test}

To test the significance of differences in students and university student abilities related to MS office software and learning technology and the significance of teacher and lecturer impressions related to learning technology. Therefore, an Independent Sample t-Test 
was conducted. In addition, homogeneity testing using Levene's test was done before the difference test.

Based on the SPSS output, it was found that the value of Levene/Test for Equality of Variances was $0.812>0.05$. So, it could be interpreted that the data variance between student groups and student groups was homogeneous or the same, so that the interpretation of output independent samples t-test was guided by the values contained in the Equal variances assumed column. Based on the SPSS output, it could be seen that the Sig. (2-tailed) at the equal variances assumed was $0.041<0.05$. This means that hypothesis 1 , namely, there was a significant difference between the ability of students and students related to Microsoft office software and learning technology, was accepted.

This result was supported by the average value of student groups' ability related to mastery of Microsoft office and learning technology $(3,18)$, which was lower than the average value of student groups (3.30). This finding supported the research that stated that online learning for schools was a new experience for most schools compared to Higher Education; this opinion was evident from teachers' lack of technical skills (Purwanto et al., 2020). Based on the results of the study of Zhafira et al. (2020), it was found that $47 \%$ of 165 student respondents did not know about online learning media before the pandemic situation.

Based on the SPSS output, it was evident that the value of the Levene/Test for Equality of Variances was $0,848>0.05$. So, it could be interpreted that the data variance between teacher groups and lecturer groups was homogeneous with Sig. (2-tailed) at equal variances assumed $0.114>0.05$. This means that hypothesis 2 was not accepted. There was no significant difference between the perception of teachers and lecturers related to the role of learning technology in the classroom over the educational process of students. These results indicated that teachers and lecturers had a common understanding that the internet and modern technological devices in the educational process contributed positively to the process of interaction and concentration of students while learning to impact the motivation and attendance of students. In the end, it helped improve student grades and achievement.

The success of online learning was highly dependent on several integrated components, such as students, educators, learning resources, and the technology used. Online learning did not only provide assignments or online lectures. The learning model was only one direction, whereas ideally, learning must be two-way or interact with students and educators. During the pandemic, educational organizations in Indonesia were forced to be ready to provide online learning services. So, there were still many learning models that were one-way with a pattern of providing material and assignments online in its implementation. As a result, the two-way interaction was still minimalist. The advantages felt by educators and students with the implementation of SFH with online learning models were as follows: had flexibility in its implementation, reduce the potential for the spread of Covid-19 in the campus and school environment, increase students' courage in expressing ideas, opinions and asking questions free, and provide new learning model experiences. The readiness and motivation of educators to advance knowledge and skills in online learning contribute to advancing the quality of education (Duraku and Hoxha, 2020).

In the implementation of distance learning during the Covid-19 pandemic, many teachers and lecturers only assign assignments to students to work on questions, summarizing, and the like; the same is shown by Arika (2020) and Miaty (2020). Ideal learning was oriented to students' ability to solve problems, think critically, collaborate, communicate, be creative, and be innovative by using digital technology as a work tool. Educators in the digital era (Industrial era 4.0) leading to the era of Society 5.0. Must face the millennial generation. They were challenged to build effective communication and not too long to speak in one direction. Therefore, educators need to prepare an attractive presentation of learning material with an attractive design. The appearance of fashion style also needed to 
be considered: not dull, formal, but also casual, so that teachers and students look fresh. Efforts by governments and other stakeholders were needed to collaborate improving the development of online learning infrastructure, equip educators and students with standardized home-based teaching/learning tools, conduct online teacher training, develop scale education online national entry in the national strategic plan, and supported academic research into online education, especially education to help students who had difficulties in online learning to overcome the shortcomings of implementing online learning during SFH. Previous research (Steele et al., 2019) shows that virtual applications integrated into the curriculum can improve students' cognitive and creative skills through a student-centered environment. Similarly, in the empirical study of Sandhu and de Wolf (2020) at the Faculty of Medical Sciences in London, the UK concluded that new ways of online teaching should be considered in the development of a new medical curriculum, as well as methods of delivering practical skills online to medical students.

Some of the disadvantages of online learning found in Indonesia today; lack of student discipline, lack of motivation, lack of student discipline, fatigue, and boredom because most were only in the form of online assignments, constraints on the internet, and technological devices. Moreover, subjects and courses related to calculation and practices were not effective if only done through online learning, limited internet access, lack of social interaction were challenges for educational organizations and stakeholders. Furthermore, impaired attention, lack of concentration and motivation, and challenges encountered in studying online have all been affected by changes in student life and have triggered both anxiety symptoms and perceived reported stress (Duraku \& Hoxha, 2020). Keep in mind that technology was created to complement and assist humans in carrying out their duties and responsibilities, not to replace their overall role. From these findings, it was evident that the role of teachers and lecturers cannot be replaced entirely by technology. Students in the learning process still need the physical existence of an educator because its function was not only to convey material and transfer knowledge but also to educate character and teach how to interpret and live life better. This is the essential role of educators as role models of students that any technology cannot replace. This opinion was supported by the results of (Hartman et al., 2019) research which showed that 78 percent of Generation $\mathrm{Z}$ respondents believed that teachers play an essential role in learning. Therefore, a blended learning program or integration between online and offline is the best learning program to be implemented in education. Student overload and circumstances caused by Covid-19 can best be managed by offering flexibility both in terms of opportunities to engage with the teaching process and study and assessments. Education organizations should also enable equal access for all by designing appropriate courses and materials based on the students' needs. While developing strategies, universities should aim to advance equal opportunities for all students and create affordable and sustainable programs.

In education, education practitioners in Indonesia, who were initially forced to, eventually had to adopt new learning models following the characteristics of the Industrial Revolution 4.0 towards Society 5.0. This learning model was different from the previous curriculum pattern where students were challenged from an early age to learn independently by using various media and technology, civilizing group work, and being able to collaborate and be confident in their abilities. According to Steele et al. (2019), virtual applications integrated into the curriculum could improve students' cognitive and creative skills through a student-centered environment.

\section{Conclusion}

The ability of students and university students to master MS office software and technical learning tools was included in the Fair level in which university students had higher 
average scores than students. Students use a variety of learning technology tools during the study from the home period. Most students use smartphones combined with the use of a PC or laptop. The internet usage of teachers and lecturers in classrooms was in the high category. The teachers and lecturers had a positive impression of the technological tools used in education because they contributed highly to the interaction and concentration of students in lessons, student grades, and student achievement. However, this research still had disadvantages, namely the generalization of research results. Therefore, further research was needed on problem-based, collaborative online learning and other models with more equitable sampling techniques in all provinces in Indonesia to represent the conditions of learning in Indonesia in general. The research could also be carried out by taking samples in certain areas and examined in more detail, for example, the impact of online learning on students' grades or achievements. In subsequent studies, the impact of online learning systems on teacher job satisfaction and performance in online education could also be considered.

\section{References}

Abidah, A., Hidaayatullaah, H., Simamora, R., Fehabutar, D., \& Mutakinati, L. (2020). The Impact of Covid-19 to Indonesian Education and Its Relation to the Philosophy of "Merdeka Belajar." Studies in Philosophy of Science and Education, 1(1), 38-49. https://doi.org/10.46627/sipose.v1i1.9.

Basilaia, G., \& Kvavadze, D. (2020). Transition to Online Education in Schools during a SARS-CoV-2 Coronavirus (COVID-19) Pandemic in Georgia. Pedagogical Research, 5(4). https://doi.org/10.29333/pr/7937.

Basri, W., Alandejani, J., \& Almadani, F. (2018). ICT adoption impact on students' academic performance: Evidence from Saudi universities. Education Research International, 2018. https://doi.org/10.1155/2018/1240197.

Bøe, T. (2018). E-learning technology and higher education: the impact of organizational trust. Tertiary Education and Management, 24(4), 362-376. https://doi.org/10.1080/13583883.2018.1465991.

Dewi, W. (2020). Dampak Covid-19 terhadap implementasi pembelajaran daring di Sekolah Dasar. Edukatif: Jurnal Ilmu Pendidikan, 2(1), 55-61. https://doi.org/10.31004/edukatif.v2i1.89.

Elsy, P. (2020). Elderly care in the society 5.0 and kaigo rishoku in Japanese hyper-ageing society. Jurnal Studi Komunikasi, 4(2), 435-452. https://doi.org/10.25139/jsk.v4i2.2448.

Firman, F., \& Rahayu, S. (2020). Pembelajaran Online di Tengah Pandemi Covid-19. Indonesian Journal of Educational Science (IJES), 2(2), 81-89. https://doi.org/10.31605/ijes.v2i2.659.

Gikas, J., \& Grant, M. M. (2013). Mobile computing devices in higher education: Student perspectives on learning with cellphones, smartphones \& social media. Internet and Higher Education, 19, 18-26. https://doi.org/10.1016/j.iheduc.2013.06.002.

Hartman, R., Townsend, M., \& Jackson, M. (2019). Educators' perceptions of technology integration into the classroom: a descriptive case study. Journal of Research in Innovative Teaching \& Learning, 12(3). https://doi.org/10.1108/jrit-03-2019-0044.

Herliandry, L., Nurhasanah, N., Suban, M., \& Kuswanto, H. (2020). Pembelajaran Pada Masa Pandemi Covid-19. Jurnal Teknologi Pendidikan, 22(1), 65-70. https://doi.org/10.21009/jtp.v22i1.15286.

Hikmatiar, H., Sulisworo, D., \& Wahyuni, M. (2020). Pemanfaatan Learning Manegement 
System Berbasis Google Classroom Dalam Pembelajaran. Jurnal Pendidikan Fisika, 8(1), 78-86. https://doi.org/10.26618/jpf.v8i1.3019.

Khusniyah, N., \& Hakim, L. (2019). Efektivitas Pembelajaran Berbasis Daring: Sebuah Bukti Pada Pembelajaran Bahasa Inggris. Jurnal Tatsqif, 17(1), 19-33. https://doi.org/10.20414/jtq.v17i1.667.

Kumar, V., \& Nanda, P. (2018). Social media in higher education: A framework for continuous engagement. International Journal of Information and Communication Technology Education, 15(1), 97-108. https://doi.org/10.4018/ijicte.2019010107.

Kuntarto, E. (2017). Keefektifan Model Pembelajaran Daring Dalam Perkuliahan Bahasa Indonesia di Perguruan tinggi. Journal Indonesian Language Education and Literature, 3(1), 99-110. https://doi.org/10.24235/ileal.v3i1.1820.

Margalina, V., Heredero, C., Botella, J., \& Martinez, A. (2014). The Role of Relational Coordination in Final Teacher Satisfaction in e-learning. Procedia Technology, 16, 365-375. https://doi.org/10.1016/j.protcy.2014.10.102.

Miaty. (2020). Pembelajaran Berbasis During Selama Pandemi Covid-19.

Mustakim. (2020). Efektivitas Pembelajaran Daring Menggunakan Media Online Selama Pandemi Covid-19 Pada Mata Pelajaran Matematika the Effectiveness of E-Learning Using Online Media During the Covid-19 Pandemic in Mathematics. Al Asma: Journal of Islamic Education, 2(1), 1-12.

Mustofa, M., Chodzirin, M., Sayekti, L., \& Fauzan, R. (2019). Formulasi Model Perkuliahan Daring Sebagai Upaya Menekan Disparitas Kualitas Perguruan Tinggi. Walisongo Journal of Information Technology, 1(2), 151-160. https://doi.org/10.21580/wjit.2019.1.2.4067.

Nastiti, F., \& Abdu, A. (2020). Kajian: Kesiapan Pendidikan Indonesia Menghadapi Era Society 5.0. Edcomtech Jurnal Kajian Teknologi Pendidikan, 5(1), 61-66. https://doi.org/10.17977/um039v5i12020p061.

Pratiwi, E. W. (2020). Dampak Covid-19 Terhadap Kegiatan Pembelajaran Online Di Perguruan Tinggi Kristen Di Indonesia. Perspektif Ilmu Pendidikan, 34(1), 1-8. https://doi.org/10.21009/pip.341.1.

Purwanto, A., Pramono, R., Asbari, M., Hyun, C., Wijayanti, L., \& Putri, R. (2020). Studi Eksploratif Dampak Pandemi COVID-19 Terhadap Proses Pembelajaran Online di Sekolah Dasar. EduPsyCouns: Journal of Education, Psychology and Counseling, 2(1), 1-12. https://ummaspul.e-journal.id/Edupsycouns/article/view/397.

Puspitasari, P., Sari, P., Putri, J., \& Wuryani, W. (2018). Pengaruh Penggunaan Media Pembelajaran terhadap Motivasi Belajar Mahasiswa IKIP Siliwangi. Parole: Jurnal Pendidikan Bahasa Dan Sastra Indonesia, 1(2), 227-232. https://doi.org/10.22460/p.v1i2p\%25p.243.

Putria, H., Maula, L., \& Uswatun, D. (2020). Analisis Proses Pembelajaran Dalam Jaringan (DARING) Masa Pandemi COVID-19 pada Guru Sekolah Dasar. Jurnal Basicedu, 4(4), 861-870. https://doi.org/10.31004/basicedu.v4i3.416.

Sianturi, S. (2018). Meningkatkan Motivasi Belajar Melalui Evaluasi E-Learning Pada Institusi Keperawatan Di Jakarta Dan Depok. Jurnal Pendidikan Keperawatan Indonesia, 4(2), 122-130. https://doi.org/10.17509/jpki.v4i2.11563.

Sobron, A., Bayu, B., Rani, R., \& Meidawati, M. (2019). Pengaruh Daring Learning terhadap Hasil Belajar IPA Siswa Sekolah Dasar Sobron. Seminar Nasional Sains Dan Enterpreneurship VI Tahun 2019. https://doi.org/10.31004/basicedu.v4i2.332.

Steele, P., Johnston, E., Lawlor, A., Smith, C., \& Lamppa, S. (2019). Arts-Based 
Instructional and Curricular Strategies for Working With Virtual Educational Applications. Journal of Educational Technology Systems, 47(3), 411-432. https://doi.org/10.1177/0047239518803286.

Widodo, T., \& Kadarwati, S. (2013). Higher order thinking berbasis pemecahan masalah untuk meningkatkan hasil belajar berorientasi pembentukan karakter siswa. Cakrawala Pendidikan, 5(1). https://doi.org/10.21831/cp.v5i1.1269.

Wijayanengtias, M., \& Claretta, D. (2020). Student Perceptions of Online Learning During the Covid-19 Pandemic. Kanal: Jurnal Ilmu Komunikasi, 9(1), 16-21. https://doi.org/10.21070/kanal.v9i1.685.

Zhafira, N. H., Ertika, Y., \& Chairiyaton. (2020). Persepsi Mahasiswa Terhadap Perkuliahan Daring Sebagai Sarana Pembelajaran Selama Masa Karantina Covid-19. Jurnal Bisnis Dan Kajian Strategi Manajemen, 4, 37-45.

Zhang, W., Wang, Y., Yang, L., \& Wang, C. (2020). Suspending Classes Without Stopping Learning: China's Education Emergency Management Policy in the COVID-19 Outbreak. Journal of Risk and Financial Management, 13(3). https://doi.org/10.3390/jrfm13030055.

Zhu, X., \& Liu, J. (2020). Education in and After Covid-19: Immediate Responses and Long Term Visions. Postdigital Science and Education, 2(3), 695-699. https://doi.org/10.1007/s42438-020-00126-3. 